\title{
Prevalence of Work-related Musculoskeletal Symptoms among Dental Students at Ss. Cyril and Methodius University Dental School in Skopje
}

\author{
Vasilka Rendzova ${ }^{1}$, Julijana Nikolovska ${ }^{2}$, Sonja Apostolska ${ }^{1}$, Nikola Petričević ${ }^{3 *}$ \\ ${ }^{1}$ Department of Restorative Dentistry and Endodontics, Faculty of Dental Medicine, University "Ss. Cyril and Methodius," Skopje, \\ Republic of Macedonia; 'Department of Prosthodontics, Faculty of Dental Medicine, University "Ss. Cyril and Methodius", \\ Skopje, Republic of Macedonia; ${ }^{3}$ Department of Removable Prosthodontics, School of Dental Medicine, University of Zagreb, \\ Zagreb, Republic of Croatia
}

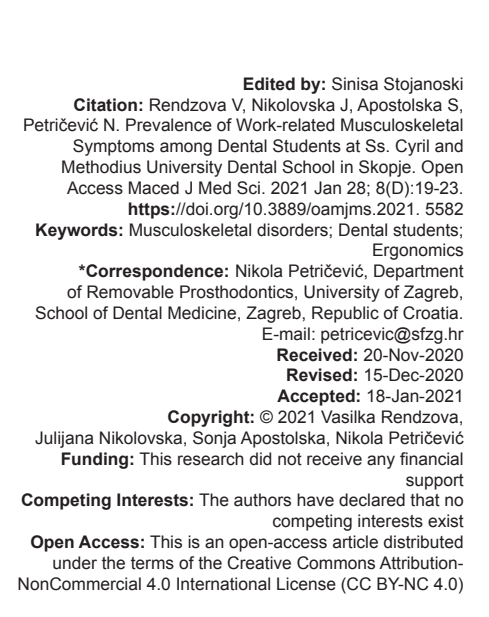

\section{Abstract}

AIM: The aim of the study was to investigate the prevalence of work-related musculoskeletal problems in $3^{\text {rd }}, 4^{\text {th }}$, and final year of study in Ss. Cyril and Methodius University Dental School.

METHODS: All $3^{\text {rd }}, 4^{\text {th }}$, and final year regular dental students were invited to take part in the study, which involved completing the extended Nordic Musculoskeletal Questionnaire. This questionnaire facilitates an assessment of troubles (ache, pain, or discomfort) with neck, shoulders, upper back, elbows, wrists/hands, low back, hips/thighs, knees, and ankles/feet.

RESULTS: Out of a maximum possible number of 146 students, 116 agreed to participate and completed the questionnaire (33 males and 83 females). The response rate was $79.5 \%$. The mean age of students was 22.6 years $(S D=1.52)$, ranging from 20 to 26 years. During the past 12 months, students have problems mostly with neck 48 (41.4\%), upper back $43(37.1 \%)$, and low back $43(37.1 \%)$. Working hours/week was $12 \mathrm{~h}$ for $3^{\text {rd }}$ year, $20 \mathrm{~h}$ for $4^{\text {th }}$, and $30 \mathrm{~h}$ for $5^{\text {th }}$-year students. There is a significant difference between the students from third study year with these from $4^{\text {th }}$ and $6^{\text {th }}$ study year regarding the neck $\left(\chi^{2}(2)=6.46, p<0.05\right)$, upper back $\left(\chi^{2}(2)=7.38, p<0.05\right)$, and low $\operatorname{back}\left(\chi^{2}(2)=13.79, p<0.05\right)$

CONCLUSIONS: This study reported high prevalence of musculoskeletal symptoms among the dental students. Preventive measures and more ergonomic recommendations are indicated.

\section{Introduction}

Musculoskeletal pain is one of the most significant occupational health hazards for healthcare professionals. Dentistry, particularly general dentistry, is considered to be one of the highest-risk professions for developing these problems, primarily due to high visual demands that result in prolonged static positions being adopted by clinicians, with movements being limited to the hand and wrist [1], [2].

Despite having physical and psychological effects, professional disorders can impact the worker's economic state and well-being on a larger scale, which contributes to more frequent absence from work and early retirement [3]. Based on the data received from the occupational information network and US Department of Labor database, dentistry was ranked first as a profession that has the worst impact on the health of the worker [4].

Musculoskeletal disorders (MSD) are one of the most common types of work-related diseases that affect health workers, especially dentists. There are multiple factors that contribute to the formation of the MSDs among the dentists [5]: Continuous movements, insufficient lighting, improper of the body during work, psychological stress, genetics, physical conditions, age, and weight [6], [7]. On the other hand, some studies have shown that musculoskeletal pain was negatively correlated with years of experience [8], [9]. It has been hypothesized that more experienced dentists learn to adjust their work posture to avoid such problems, or that those dentists with severe work-related MSDs have left the profession [10]. Therefore, this suggests that even dental students can manifest early signs of MSD during their years of training. These findings were supported by research that revealed that more than $70 \%$ of dental students experienced neck, shoulder, and lower back pain (LBP) as early as the $3^{\text {rd }}$ year of their dental training [11], [12].

An assessment of the MSD among the dental students and the underlying factors associated with it is required to more clearly elucidate the nature of this important issue for dental students [13]. Ergonomics is a science that is concerned with design of products and regulations that assure maximal utility and safety 
during work. It also studies the relationship between the worker, the equipment, and the work environment. The implementation of ergonomic conditions and principles in the work place is important element in the prevention of MSDs and the improvement of the productivity and effectiveness of the dentist for a longer period of time [10].

Having this into consideration, the aim of the study was to investigate the prevalence of work-related musculoskeletal problems in $3^{\text {rd }}, 4^{\text {th }}$, and final year of study in Ss. Cyril and Methodius University Dental School.

\section{Methods}

This cross-sectional descriptive study was conducted in October 2018 at the Ss. Cyril and Methodius University Dental School. This study examined a sample of 116 regular dental students of $3^{\text {rd }}(33), 4^{\text {th }}(47)$, and final year (36) of their study, neither of them was married or had children. They were given to complete an extended Nordic Musculoskeletal Questionnaire [14]. This questionnaire facilitates an assessment of troubles (ache, pain, or discomfort) with neck, shoulders, upper back, elbows, wrists/hands, low back, hips/thighs, knees, and ankles/feet. The second part was consisted of questions addressing the MSDs, the presence of genetic predisposition, the frequency of pain-killer usage, and questions regarding diagnosis and request for medical help among patients with these disorders in past 12 months. The obtained results were analyzed with descriptive statistical analysis and Chisquare test.

\section{Results}

Out of a maximum possible number of 146 students, 116 agreed to participate and completed the questionnaire (33 males and 83 females). The response rate was $79.5 \%$. The mean age of students was 22.6 years $(S D=1.52)$, ranging from 20 to 26 years (Table 1). Working hours/week was $12 \mathrm{~h}$ for $3^{\text {rd }}$ year, $20 \mathrm{~h}$ for $4^{\text {th }}$, and $30 \mathrm{~h}$ for $5^{\text {th }}$-year students.

Table 1: Participants of the study

\begin{tabular}{llll}
\hline Demographic characteristics & $\mathrm{n}$ & Mean $(\mathrm{SD})$ & Total \\
\hline Age & 33 & $23.1(\mathrm{SD}=1.56)$ & Min-Max $=20-26$ \\
M & 83 & $22.4(\mathrm{SD}=1.49)$ & Mean $=22.6(\mathrm{SD}=1.53)$ \\
F & & & \\
Height & 33 & $180.5(\mathrm{SD}=5.77)$ & Min-Max $=155-193$ \\
M & 83 & $169.1(\mathrm{SD}=6.40)$ & Mean $=172.3(\mathrm{SD}=8.08)$ \\
F & & & \\
Weight & 33 & $77.5(\mathrm{SD}=13.95)$ & Min-Max $=55-95$ \\
M & 83 & $61.3(\mathrm{SD}=9.99)$ & Mean $=75.0(\mathrm{SD}=13.39)$ \\
F & & & \\
\hline
\end{tabular}

Table 3: Upper back pain

\begin{tabular}{lllll}
\hline Upper back during past 12 months & 3 year & 4 year & 5 year & Total \\
\hline Students without upper back pain & & & & \\
$\quad$ Count & 26 & 30 & 17 & 73 \\
\% within upper back & 35.6 & 41.1 & 23.3 & 100 \\
$\quad$ \% within year & 78.8 & 63.8 & 47.2 & 62.9 \\
Students with upper back pain & & & & \\
$\quad$ Count & 7 & 17 & 19 & 43 \\
$\quad$ \% within upper back & 16.3 & 39.5 & 44.2 & 100.0 \\
\% within year & 21.2 & 36.2 & 52.8 & 37.1 \\
\hline
\end{tabular}

During the past 12 months, 48 students had problems mostly with neck (Table 2), 43 with upper back (Table 3 ), and 43 with lower back 43 (Table 4 ). There are no significant differences between the groups for the other regions (shoulders, elbows, wrists/hands, hips/thighs, knees, and ankles/feet).

Table 2: Neck pain

\begin{tabular}{lllll}
\hline Neck pain during past 12 months & 3 year & 4 year & 5 year & Total \\
\hline $\begin{array}{l}\text { Students without neck pain } \\
\quad \text { Count }\end{array}$ & 23 & 30 & 15 & 68 \\
$\quad$ \% within neck & 33.8 & 44.1 & 22.1 & 100.0 \\
$\quad$ \% within year & 69.7 & 63.8 & 41.7 & 58.6 \\
$\quad \begin{array}{l}\text { Students with neck pain } \\
\quad \text { Count }\end{array}$ & 10 & 17 & 21 & 48 \\
\% within neck & 20.8 & 35.4 & 43.8 & 100.0 \\
$\quad \%$ within year & 30.3 & 36.2 & 58.3 & 41.4 \\
\hline
\end{tabular}

Our study showed that as many as $58.3 \%$ of students in their last year of study complained of neck pain in the last month and $41.4 \%$ in the past 12 months (Table 2). There is a significant difference between the students from $3^{\text {rd }}(20.8 \%)$ study year with these from $4^{\text {th }}(35.4 \%)$ and $5^{\text {th }}(43.8 \%)$ study year regarding the neck $\left(\chi^{2}(2)=6.46, p<0.05\right)$. There are no differences between students from $4^{\text {th }}$ and $5^{\text {th }}$ year of study.

Table 4: LBP

\begin{tabular}{lllll}
\hline Lumbar region during last 12 months & 3 year & 4 year & 5 year & Total \\
\hline Students without LBP & & & & \\
$\quad$ Count & 28 & 30 & 15 & 73 \\
\% within Ib2 & 38.4 & 41.1 & 20.5 & 100.0 \\
$\quad$ \% within year & 84.8 & 63.8 & 41.7 & 62.9 \\
Students with LBP & & & & \\
$\quad$ Count & 5 & 17 & 21 & 43 \\
\% within Ib2 & 11.6 & 39.5 & 48.8 & 100.0 \\
$\quad \%$ within year & 15.2 & 36.2 & 58.3 & 37.1 \\
\hline LBP: Lower back pain & & & &
\end{tabular}

Problems with the upper back were reported by $31 \%$ in the last month and $37.1 \%$ of students in the past 12 months. Most of the students who had problems with upper back were from $4^{\text {th }}$ and $5^{\text {th }}$ year of study $(39,5 \%$ and $44,2 \%)$. There is a significant difference between the students from $3^{\text {rd }}$ study year with these from $4^{\text {th }}$ and $5^{\text {th }}$ study year regarding the upper back $\left(\chi^{2}(2)=7.38\right.$, $p<0.05)$. Compared to the year of study, as many as $52.8 \%$ of the surveyed students from the $5^{\text {th }}$ year of study complained of the upper back pain.

Problems with the lumbar region were reported by $36.2 \%$ of students in the last month and $37.1 \%$ in last 12 months. Most of the students who had problems with upper back were from 4th and 5th year of study $(39,5 \%$ and $44,2 \%)$. There was a significant difference between the students from $3^{\text {rd }}, 4^{\text {th }}$, and $5^{\text {th }}$ year of study $\left(\chi^{2}(2)=\right.$ $13.79, p<0.05)$ regarding the lumbar region. Compared to the year of study, as many as $58.3 \%$ of the surveyed students from the $5^{\text {th }}$ year and only $15.2 \%$ from the $3^{\text {rd }}$ year of study complained of the lumbar region pain. 


\section{Discussion}

The term MSDs refer to injuries that affect soft tissues such as muscles, tendons, ligaments, joints, cartilage, and the nervous system. These conditions most often affect the arms and back and are known as cumulative disorders caused by trauma, repetitive movements, stress, or as a syndrome of occupational overload. MSD develops gradually within weeks, months, and years and in a longer period of time may cause disabilities.

The modified Nordic questionnaire used in this study is considered to be an acceptable method to measure the prevalence of musculoskeletal pain and has been used in a number of other similar studies [14], [15]. As participants of this study provided self-reported information, there is the potential for bias, and it could be suggested that more accurate results could be obtained using physical examinations and assessments [16].

Many authors in their studies found that there was a high prevalence of musculoskeletal pain in the upper back, lower back, and neck regions of undergraduate dental students [11], [12], [13]. Vijay and Ide in their cross-sectional study reported that the prevalence of musculoskeletal pain in their study $(79 \%)$ is in line with similar studies for both dentists, ranging from $64 \%$ to $93 \%$ and dental students, ranging from $46 \%$ to $86 \%$ [17].

Al Wazzan et al. presumed that the number of years of practice has an essential part in the occurrence of MSDs, even though younger and older dentists equally reported the same symptoms, as confirmed in the present study [18].

Other studies highlight and support the established fact that work-related MSDs (WMSD) are a major concern for dental students during their training years [19], [20].

The prevalence of occupational LBP and neck pain in dentists was reported between $33 \%$ and $>55 \%$ [21], [22], [23].

In our study, there was also a high prevalence of musculoskeletal pain in the upper back, lower back, and neck regions of undergraduate dental students especially during the past 12 months. Female students made up $71.5 \%$ of respondents in this study. There was a significant difference in these three regions between the students from $3^{\text {rd }}$ with $4^{\text {th }}$ and $5^{\text {th }}$ year of study (there are no differences between $4^{\text {th }}$ and $5^{\text {th }}$ year).

However, the young general dental practitioners often work over $8 \mathrm{~h}$ a day in the earliest years of their practice, which trigger premature occurrence of MSDs within 3 years [24].

Some authors reported increase in pain prevalence with the number of years spent in the dental school and this was more related to students in clinical years acquiring clinical skills and providing routine dental procedures [11].

Working hours/week in our study was $12 \mathrm{~h}$ for $3^{\text {rd }}$ year, $20 \mathrm{~h}$ for $4^{\text {th }}$, and $30 \mathrm{~h}$ for $5^{\text {th }}$-year students, which can be one of the reasons for the difference between students from $3^{\text {rd }}$ and $4^{\text {th }} / 5^{\text {th }}$ year of study.

The results presented in other study revealed a significant difference in the prevalence of discomfort and WMSD symptoms between dental students in their clinical and non-clinical years. This can be attributed to difference in the nature of work, practicing pattern, and working hours between clinical and non-clinical years of dental education. Khan in their study indicated that the number of clinical working hours per 0 week were statistically significant risk factors especially for hand and finger discomfort. Students with increased number of working hours per week were much more likely to report discomfort in hands and fingers [25].

A literature search revealed that forward head posture and neck position may predispose to tension neck syndrome with associated symptoms of pain, stiffness, and muscle spasm with referring pain between shoulder blades and these findings were in agreement with the findings of this study [26].

Bending and twisting of the neck during clinical work were found to be highly associated with neck and upper-back discomfort and this finding was consistent in the literature as neck extension, flexion, and rotation were identified as possible risk factors contributing to neck discomfort and pain [27].

Our study identified neck pain as being the most prevalent area of musculoskeletal pain $(41.4 \%)$ especially in $5^{\text {th }}$-year students, where the number of students who complained of neck pain is almost twice as high as in $3^{\text {rd }}$-year students with the same problems. This may be due primarily to poor body posture when working with patients as well as most practical classes in the $4^{\text {th }}$ and $5^{\text {th }}$ year.

Rising et al. reported that there was a significant year-by-year increase of a perception that dental procedures aggravate musculoskeletal pain among dental students from California [11]

Furthermore, hand pain was present with a significantly lower percentage compared to the pain in the back, neck, and shoulders which is connected and dependent on the area of specialty. Our research included students attending practical classes in different dental areas of specialty, which share similar positioning of the neck, shoulders, and spine while working. The application of force at work and the machine vibrations are connected to only few dental areas that require usage of hands and fingers, which gives us the reason behind low percentage of complaints connected to hand and finger disorders. 
The present findings show that pain in the upper and lower back, increased with the increased years of practice supporting previous findings.

This finding is significant as highlighted in a study by Myers and Myers which showed that the main health complaint among dentists - causing chronic concern, medical care and leading to absenteeism - was LBP, quoting a slightly higher prevalence of $62 \%[28]$.

Working environment and its characteristics were considered as major factors affecting the prevalence of MSD [29], [30]. Having a comfortable dental chair with a back support is likely to decrease the prevalence of lower back discomfort [25].

Vijay and Ide found that there is a significant association between the presence of LBP and the sitting position using a comfortable work stool $(p<0.05)$ and having a back support $(p<0.05)$. This means that students who used a comfortable work stool with a back support were less likely to have LBP. In regards to the dental stool, it is recommended to obtain a stool that offers neutral back, neck, and shoulder support for optimal posture and possesses an adjustable height and tilt [17].

In our study, most students work with patients in a standing position, which can be one of the reasons for the pain in the upper and lower back. It has been proven that postures which may exert a higher pressure on intervertebral disk as well as prolonged spinal hypomobility are among important factors leading to degenerative changes in the lumbar spine and subsequent LBP.

Pargali found that the distribution of workrelated risk factors did not significantly different between those dentists with and without pain complaint, so they concluded that dentistry is probably not an initial factor for development of neither LBP nor neck pain, but it could accelerate the process and thus, increase the severity of symptoms [27].

Poor posture in dentists frequently leads to MSD, which can result in dentists reducing their working hours and taking early retirement [31].

There are a number of different approaches which have previously been suggested to prevent the onset and progression of occupational musculoskeletal pain, including improving physical fitness, improving work posture, regular stretching, and health promotion [29], [30].

Due to its ability to improve musculoskeletal and cardiovascular function, physical exercise may be useful for improving back function and preventing development of work-related MSDs [7], [32]. Some studies suggest that ergonomic advice on improving physical activity should be offered during the process of education [33].

\section{Conclusions}

This study reported high prevalence of musculoskeletal symptoms among the dental students. Preventive measures and more ergonomic recommendations are indicated.

\section{References}

1. Graham C. Ergonomics in dentistry, Part 1. Dent Today 2002;21(4):98-103

PMid:11957243

2. Hayes M, Cockrell D, Smith D. A systematic review of musculoskeletal disorders among dental professionals. Int $J$ Dent Hyg. 2009;7(3):159-65.

PMid:19659711

3. Fulton-Kehoe D, Franklin G, Weaver M, Cheadle A. Years of productivity lost among injured workers in Washington State: Modeling disability burden in workers' compensation. Am J Ind Med. 2000;37(6):656-62. https://doi.org/10.1002/ (sici)1097-0274(200006)37:6<656::aid-ajim10>3.0.co;2-c PMid: 10797509

4. LaRochelleNR. VirginiaCommonwealthUniversity. Work-Related Musculoskeletal Disorders among Dentists and Orthodontists; 2017. Available from: https//www.scholarscompass.vcu.edu/ etd/4765. https://doi.org/10.25772/6eef-1634

5. Stewart WF, Ricci JA, Chee E, Morganstein D, Lipton R. Lost productive time and cost due to common pain conditions in the US workforce. JAMA. 2003;290(18):2443-54. https://doi. org/10.1001/jama.290.18.2443

PMid:14612481

6. Smith DR, Wei N, Zhang YJ, Wang RS. Musculoskeletal complaints and psychosocial risk factors among physicians in mainland China. Int J Ind Ergon. 2006;36:599-603. https://doi. org/10.1016/j.ergon.2006.01.014

7. De Sio S, Traversini V, Rinaldo F, Colasanti V, Buomprisco G, Perri $\mathrm{R}$, et al. Ergonomic risk and preventive measures of musculoskeletal disorders in the dentistry environment: An umbrella review. PeerJ. 2018;6:e4154. https://doi.org/10.7717/ peerj. 4154 PMid:29362689

8. Burke FJ, Main JR, Freeman R. The practiceof dentistry: An assessment of reasons for premature retirement. $\mathrm{Br}$ Dent $\mathrm{J}$. 1997;182(7):250-4. https://doi.org/10.1038/sj.bdj.4809361 PMid:9134812.

9. Rucker LM. Technology meets ergonomicsin the dental clinic: New toys for old games? J Am Coll Dent. 2000;67(2):26-9. PMid:10941230

10. Sarkar PA, Shigli AL. Ergonomics in general dental practice. Peoples J Sci Res. 2012;5(1):56-60.

11. Rising DW, Bennett BC, Hursh K. Reports of body pain in a dental student population. J Am Dent Assoc. 2005;136(1):81-6. PMid:15693502

12. Bruers JJ, Trommelen LE, Hawi P, Brand HS. Musculoskeletal disorders among dentists and dental students in the Netherlands. Ned Tijdschr Tandheelkd. 2017;124(11):581-7. https://doi. org/10.5177/ntvt.2017.11.17128 


\section{PMid:29136048}

13. Dajpratham P, Ploypetch $T$, Kiattavorncharoen S. Prevalence and associated factors of musculoskeletal pain among the dental personnel in a dental school. J Med Assoc Thai. 2011;93(6):714. PMid:20572377

14. Kuorinka I, Jonsson B, Kilborn A, Vinterberg $\mathrm{H}$, Biering SF, Andersson G, et al. Standardised Nordic questionnaires for the analysis of musculoskeletal symptoms. Appl Ergon. 1987;18(3):233-37. https://doi. org/10.1016/0003-6870(87)90010-x PMid: 15676628

15. Adnan $\mathrm{F} \mathrm{K}$, Ayfer T, Cankat TD, Demir T, Kavrut $\mathrm{R}$. Musculoskeletal disorders in left-and right-handed Turkish dental students. Int J Neurosci. 2005;115(2):255-66. https://doi. org/10.1080/00207450590519517 PMid: 15764005

16. Finsen L, Christensen H, Bakke M. Musculosceletal disorders among dentists and variation in dental work. Appl Ergon. 1998;29(2):119-25. https://doi.org/10.1016/ s0003-6870(97)00017-3 PMid:9763237

17. Vijay $S$, Ide M. Musculoskeletal neck and back pain in undergraduate dental students at a UK dental school a crosssectional study. Br Dent J. 2016;221(5):241-5. https://doi. org/10.1038/sj.bdj.2016.642

PMid:27608577

18. Al Wazzan KA, Almas K, Al Shethri SE, Al Qatani M. Back and neck problems among dentists and dental auxillaries. J Contemp Dent Pract. 2001;2(3):17-30. https://doi.org/10.5005/ jcdp-2-3-1

PMid:12167924

19. Chowanadisai S, Kukiattrakoon B, Yapong B. Occupational health problems of dentists in Southern Thailand. Int Dent J. 2000;50(1):36-40. https://doi.org/10.1111/j.1875-595x.2000. tb00544.x PMid:10945178

20. De Carvalho MV, Soriano EP, de França C. Workrelated musculoskeletal disorders among Brazilian dental students. J Dent Educ. 2009;73(5):624-30. https://doi. org/10.1002/j.0022-0337.2009.73.5.tb04737.x

PMid: 19433537

21. Szymanska J. Disorders of the musculoskeletal system among dentists from the aspect of ergonomics and prophylaxis. Ann Agric Environ Med. 2002;9(2):169-73. PMID:12498585

22. Ratzon NZ. Musculoskeletal symptoms among dentists in relation to work posture. Work. 2000;15(3):153-8. PMid: 12441484

23. Rendzova V, Apostolska S, Eftimoska M, Džipunova B,
Filipovska V. Work related muskuloskeletal disorders among dentists at the university dental clinic in Skopje. Stomatol Glas Srbije. 2018;65(2):89-96. https://doi.org/10.2478/sdj-2018-0009

24. Alyahya F, Algarzaie K, Alsubeh $\mathrm{Y}$, Khounganian R. Awareness of ergonomics and work-related musculoskeletal disorders among dental professionals and students in Riyadh, Saudi Arabia. J Phys Ther Sci. 2018;30(6):770-6. https://doi. org/10.1589/jpts.30.770

\section{PMid:29950762}

25. Khan SA, Chew KW. Effect of working characteristics and taught ergonomics on the prevalence of musculoskeletal disorders amongst dental students. BMC Musculoskelet Disord. 2013;14(1):118. https://doi.org/10.1186/1471-2474-14-118

26. Valachi B, Valachi K. Mechanisms leading to musculoskeleta disorders in dentistry. J Am Dent Assoc. 2003;134(10):1344-50. https://doi.org/10.14219/jada.archive.2003.0048 PMid:14620013

27. Pargali N, Jowkar N. Prevalence of musculoskeletal pain among dentists in Shiraz, Southern Iran. Int J Occup Environ Med. 2010;1(2):69-74

PMid:23022788

28. Myers HL, Myers LB. Its difficult being a dentist: Stress and health in the general dental practitioner. Br Dent J. 2004;197(2):89-93. https://doi.org/10.1038/sj.bdj.4811476

PMid:15272347

29. Hokwerda OO, Wouters JA, de Ruijter RA. Ergonomic Requirements for Dental Equipment, Guidelines and Recommendations for Designing, Constructing and Selecting Dental Equipment; 2006.

30. Ahearn DJ, Sanders MJ, Turcotte C. Ergonomic design for denta offices. Work. 2010;35(4):495-503. https://doi.org/10.3233/ wor-2010-0986 PMid:20448328

31. Morse T, Bruneau H, Dussetschleger J. Musculoskeletal disorders of the neck and shoulder in the dental professions. Work. 2010;35(4):419-29. https://doi.org/10.3233/ wor-2010-0979

PMid:20448321

32. Harreby M, Hesselsoe G, Kjer J, Neergaard K. Low back pain and physical exercise in leisure time in 38-year-old men and women: A 25-year prospective cohort study of 640 school children. Eur Spine J. 1997;6(3):181-6. https://doi.org/10.1007/ bf01301433

PMid:9258636

33. ProperKI,Koning M, VanderBeekAJ. Theeffectiveness ofworksite physical activity programs on physical activity, physical fitness, and health: A critical review. Clin J Sport Med. 2003;13(2):10617. https://doi.org/10.1097/00042752-200303000-00008

PMid:12629429 